\title{
Determinants of Default in Lithuanian Peer-To-Peer Platforms
}

The article analyses the factors that determine the probability of debtors' default in the Lithuanian peer-topeer market. The results of this study are compared with previous research.

Keywords: personal finance, borrowing decisions, lending services, borrowers' default.

Straipsnyje analizuojama, kokie veiksniai lemia skolininkų nemokumo tikimybę Lietuvos savitarpio skolinimosi rinkoje. Gauti rezultatai lyginami su ankstesnių tyrimų rezultatais.

Raktiniai žodžiai: asmeniniai finansai, skolinimosi sprendimai, kreditavimo rinka, skolininkų nemokumas.

\section{Introduction}

Households and businesses seek for external funding, which is crucial for higher consumption, larger development and execution of financial plans. At this point, the demand which arises from the need of extra funds is fulfilled by the credit market. The main players in this market are banks or other financial institutions, such as credit unions, which act as an intermediary between lenders and borrowers, or payday loan providers. The constantly evolving information technologies, digitalization process or Blockchain innovations help to create new credit alternatives, which take an increasing share of the market from the traditional providers. One of these alternatives is peer-to-peer (p2p) lending platforms, which allow us to lend and borrow money among active platform members without the intervention of other financial intermediaries. The financial resources are transferred directly from individuals with capital surplus (investor side) to those with capital deficit (borrower side). Investors face all the associated risks with the issuance of the loan. One of the main is credit risk, which is understandable as the risk which arises from the debtor's failure to fulfil their financial obligations. Consequently, inappropriate loan's credit risk assessment can cause losses and vice versa, proper assessment can result in higher returns, which is the main goal of any investment.

Just because the world's first p2p lending platform was launched just more

Asta GAIGALIENE - PhD, associate professor at Finance Department, Faculty of Economics and Management, Vytautas Magnus University, Lithuania. Address: S. Daukanto str. 28, LT-44248, Kaunas, Lithuania. Phone: +370 37 327856. E-mail: asta.gaigaliene@vdu.lt

Dovydas ČESNYS - MBA from Vytautas Magnus University, graduate student of the Faculty of Economics and Management. Address: S. Daukanto str. 28, Kaunas, Lithuania. E-mail: dovydas.cesnys@vdu.lt 
than a decade ago (Lichtenwald, 2014), the evaluation of credit risk factors on borrowing platforms has become an interesting object of research among scientists and other interested parties. Different authors, C. Serrano-Cinca, B. Gutiérrez-Nieto and L. López-Palacios (2015), R. Emekter et al. (2015), Y. Guo et al (2016), M. Pokorná and M. Sponer (2016), H. Z. Ma and X. R. Wang (2016), X. Lin, X. Li, Z. Zheng (2017) and the others analysed different approaches of credit risk in p2p. However, the research results were different and there was no consensus about factors or market subjects' behaviour, which would signalize about default in $\mathrm{p} 2 \mathrm{p}$ platforms. Moreover, it is important to mention that most research is concentrated in countries with mostly developed p2p markets: USA, China, United Kingdom, Germany, etc., but there is a lack of that kind of studies in countries with less developed $\mathrm{p} 2 \mathrm{p}$ markets. Lithuania could be one example where we have the lowest household saving rates in Europe and where investment culture is just emerging. That is why it is necessary to update existing studies and assess the impact of credit risk factors on default probability using these new alternative financing instruments.

Research problem: what are the main determinants of credit risk that effect the default in peer-to-peer lending platforms in Lithuania?

Research aim: to identify the key determinants of credit risk that influence the default in the Lithuanian peer-to-peer lending platforms.

\section{Research objectives:}

1. To define the concept and models of peer-to-peer platforms.

2. To systematise the previous empirical research results and to identify the possible credit risk factors on peer-to-peer platforms.

3. To develop methodology for assessment of borrowers' default determinants in $\mathrm{p} 2 \mathrm{p}$ platforms.

4. To apply the methodology of assessment of borrowers' default determinants in the Lithuanian $\mathrm{p} 2 \mathrm{p}$ platforms.

5. To summarize and compare results with previous research.

\section{Theoretical aspects of default risk in $\mathrm{p} 2 \mathrm{p}$ platforms}

The concept of $p 2 p$ platforms. In order to assess credit risk factors in $\mathrm{p} 2 \mathrm{p}$ platforms, it is important to analyse the definition of this phenomena. Even though this term is not new in the finance field (first p2p platform was established in 2005), but it does not have a clear definition, and legislators, scientists or investors are treating these platforms differently. According to a Lithuania Law on Consumer Credit, p2p platforms are defined as "an informational system, which is managed by the operator of that platform" and p2p lending as an "activity, where lenders (creditors) provide or pledge to provide a consumer credit through p2p platform" (No. XII-1989). Moreover, $\mathrm{p} 2 \mathrm{p}$ platforms are customized for both, individuals and businesses. In scientific literature, this term is defined in different ways. P2p platforms are based on the digital space, involving one or a group of market individuals, who use the same platform without participation of financial intermediaries such as banks, credit unions (Wei, 2015). C. Serrano-Cinca, B. Gutiérrez-Nieto and L. López-Palacios (2015) define p2p platforms as financial innovation that combine money supply 
and demand. K. Davis and J. Murphy (2016) state that $\mathrm{p} 2 \mathrm{p}$ platforms are more similar to an online auction, but in the case of loans, not goods. Good example of that would be "Ebay", "Uber". Investors can choose debtors according to their own criteria.

Y. Guo et al. (2016) explain the concept of $p 2 p$ platforms emphasizing their specific features, f.ex. loan amount and timing. The requested loan amount first appears at a loan application that is later financed by lenders (investors). The loan amounts and lenders' quantity per loan vary a lot. For example, loan of 1000 euro can be funded by one investor, who finances the whole loan, or distributed among a number of investors with different amounts of contribution. Timing is another crucial aspect of such kind of borrowing. If the whole loan amount is collected via investors within a specified time-period, a loan application is accepted. Another specific feature of this borrowing market is that debtors must provide not only common compulsory information about working status, income, assets or liabilities, but also such information as detailed description of loan purpose, marital status, leisure activities or hobbies. However, by no means identifying a person's identity (Guo et al., 2016). P2p platforms create some kind of social circles or networks (platforms bring together people from the same geographical area, religion, etc.) and investors can rely not only on financial information when making investment decisions, but also additional socio-demographic aspects of borrower. According to M. Malekipirbazari and V. Aksakalli (2015), p2p platforms have several important benefits for investors, when comparing with other financial intermediaries: more dynamic environment, reduced financing costs and increased efficiency of the financial market. Additionally, from the perspective of the investor, $\mathrm{p} 2 \mathrm{p}$ platforms can generate potentially higher return on investment comparing with such alternatives as bank deposits or corporate bonds. For the debtor, on the contrary, the benefits come from bigger availability of credit and lower loan interest rates comparing with alternative credit intermediaries, f.ex. SME financing. C. SerranoCinca et al. (2015) consider p2p platforms as a risky investment alternative, such as derivatives, because these platforms do not have capital requirements like banks neither take deposits.

Model of p2p platforms. As mentioned in the previous section, due to the existing volatility in financial sector (global financial crisis in 2008, low interest rate environment, the shift from physical assets to crypto currency), investors are looking for alternative investment opportunities, such as $\mathrm{p} 2 \mathrm{p}$ platforms. As this market evolves, the models of $\mathrm{p} 2 \mathrm{p}$ platforms operation also diverge. One of the most common is so called traditional p2p platform model. According to K. Davis and J. Murphy (2016), this model directly connects investors with borrowers (Figure 1).

The role or purpose of $\mathrm{p} 2 \mathrm{p}$ platform operator in this simple model is administrative (Figure 1). Platform operators do not invest or provide any loans, because the main source of income for them is transaction fees and commissions (taxes) from investors and debtors. Moreover, an operator is responsible for debtor's credit risk assessment, loan arrangement between the investor and the debtor, additional loan administration, if a borrower does not cover their financial liabilities 


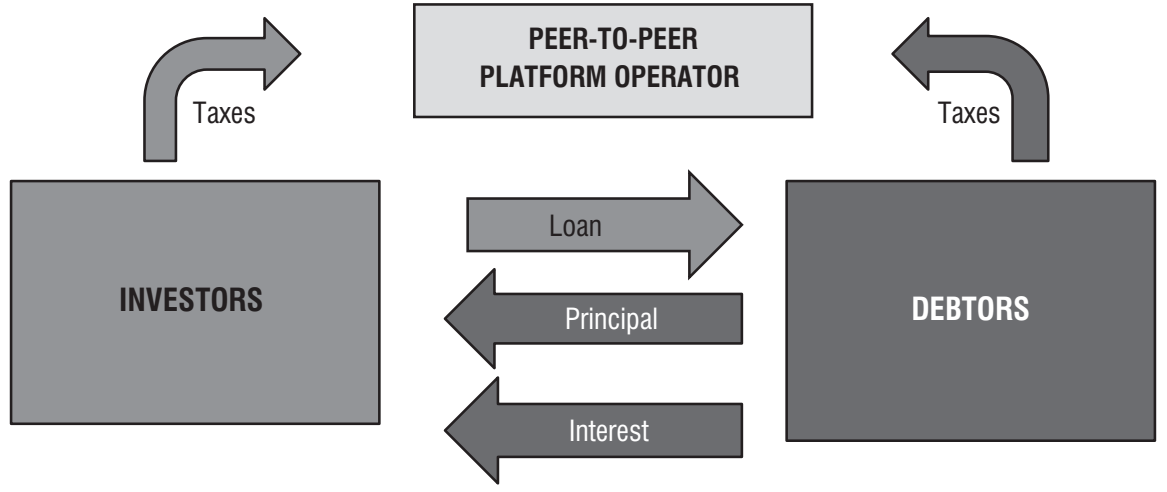

Fig. 1. Basic model of peer-to-peer platform operation

Source: created by the authors based on K. Davis and J. Murphy (2016).

(recovery of unpaid amounts). The investor's role in this model in the short-term is selection of possible investment and loan granting. In the long-term - investment monitoring and payment of taxes for a $\mathrm{p} 2 \mathrm{p}$ operator. For the debtors in the short-term the most important thing is to be accepted (according to the borrower's financial characteristics) by the platform operator. In the long-term, a borrower is responsible for payments of principal, interest and administrative fees.

One of the aspects how $\mathrm{p} 2 \mathrm{p}$ platforms differ is the type of loans that are being provided. A. Mateescu (2015), A. Fong (2015) provide comprehensive lists of $\mathrm{p} 2 \mathrm{p}$ platforms, according to the type of loan. In this paper consumer loan platforms will be analysed in more detail. It is one of the most commonly recognized types of loan raised through the $\mathrm{p} 2 \mathrm{p}$ platforms. The purpose of consumer loan mostly concentrates on the purchase of certain goods or services (for example, loan for a car, holiday, home improvements, medical expenses, and etc.). Moreover, p2p consumer loans are very popular among those who are interested in refinancing their previous loans or to achieve debt consolidation. Except from consumer loan platforms, there exist platforms that facilitate $\mathrm{p} 2 \mathrm{p}$ loans for small and medium enterprises, student loans or real estate loans. These different types of lending platforms emphasize the idea of social lending, combining two different parties and maximizing their utility.

Risk factors on p2p platforms. Most researchers agree (Mateescu, 2015; Milne and Parboteeah, 2016; Davis and Murphy, 2016; Wei, 2015) that the most important risk in $\mathrm{p} 2 \mathrm{p}$ platforms is credit risk. A credit or default risk is related to an entity's non-performance of financial liability (subject defaults), i.e., the borrower is not repaying his debts (principal + interest) on time or at all. In that case, an investor can possibly incur maximum losses due to the inappropriately assessed investment risk. According to K. Davis and J. Murphy (2016), investors in p2p platforms tend to seek for highest returns, therefore, this is where credit risk arises. S. Cai et al. (2016) distinguish another aspect of credit risk in $\mathrm{p} 2 \mathrm{p}$ platforms, which is information asymmetry. According to the authors, the 
credit risk highly correlates with existing information asymmetry while investors cannot make rational investment decisions. Information asymmetry problems are analysed by the Signaling theory, which states that disclosure of minimal attributes can significantly reduce information asymmetry. To control for this problem, p2p platform operators assign credit ratings to debtors. These ratings are based on different criteria depending on the platform. These ratings allow to partly evaluate borrowers credit risk. Another important aspect that $\mathrm{p} 2 \mathrm{p}$ operators are using to secure investors is guarantee funds. Those guarantee funds (if selected by an investor) in case of loan default, will pay back all investors' invested money into that loan(s) plus interest. However, the risk of lost money, still exists, because in the case of platform bankruptcy, invested funds are no longer protected. Moreover, some $\mathrm{p} 2 \mathrm{p}$ platforms create a secondary loan market for investors. In this market, an investor can sell their existing (confirmed) loan share to the other investors for a bigger or a lower price. This tool gives opportunity for investors to manage credit risk.

Additionally, in the line with credit risk, authors M. Pokorná and M. Sponer (2016), X. Lei (2016) identify operational risk. Due to the lack of competence, accidentally or even for a particular purpose, a platform operator can give a wrong credit rating for a borrower and due to that investors can incur losses. That is why $\mathrm{p} 2 \mathrm{p}$ platform operators and other institutions install internal audit models, which allow controlling borrower's assigned information more efficiently in the platform. There are even institutions ("online to offli$n e^{\prime \prime), ~ t h a t ~ a u t o m a t i c a l l y ~ g i v e ~ i n f o r m a t i o n ~}$ about a borrower to the platform, even before operator's assessment. Liquidity risk. According to K. Davis and J. Murphy (2016) coincidence of loan portfolio repayments makes investment quite often illiquid. A problem comes when the time for loan repayments matches and an investor faces a lack of available funds. That is why $\mathrm{p} 2 \mathrm{p}$ platforms offer secondary market. Systemic risk. As discussed above, some of the $\mathrm{p} 2 \mathrm{p}$ platforms concentrate on specific types of loans, for example, mortgage loans. If investors' loan portfolios are not well-diversified according to the loan type, investors might lose a big part of the portfolio if debtors default due to changes in economic environment. Operator risk. This risk is similar to operational risk, but in this case, a platform operator can terminate lending activities due to unprofitable business model, or some technical issues, which would require many financial resources to properly perform their obligations, even if borrowers are repaying liabilities perfectly (Milne, Parboteeah, 2016). Regulatory risk. S. Wei (2015), A. Milne and P. Parboteeah (2016) note that changes in legal framework can create various gaps, which would encourage "money laundering" or other types of fraudulent activities. And because the importance of $\mathrm{p} 2 \mathrm{p}$ platforms in the world is increasing, the platforms should be more closely monitored by central banks. Sometimes the adherence of regulation is also a complicated thing to do, because of the possible costs (new data requirements from general data protection regulation-GDPR). H. Z. Ma and X. R. Wang (2016), S. Wei (2015) also emphasize data security risk. P2p platforms exist on the internet and there is a potential risk of cyber-attacks, resulting in the leak of sensitive data (user 
privacy violations). The use of big data not only reduces information asymmetry and makes credit analysis more accurate (platform operator's perspective), but also increases the risk of data protection.

Previous empirical research. The proper assessment of the factors that determine credit risk, allows to partly control / anticipate the debtor's default. Main research results are summarized in Table 1. Majority of authors revealed that loan term, education level and years of experience has a negative effect on probability of default. It is in line with the theory, because the more experience or the higher education person has, the bigger is the probability, that a person's income will be higher, or in case of unemployment, return to the labour market would be quicker. For borrower's personal characteristics, such as gender and age, the effect is still uncertain, because of contradictory study outcomes. Same uncertain effect is for the financial determinants like loan amount and interest rate or DTI (debt-to-income ratio). In case of positive effect to borrower's default, these results would signalize rational behaviour. For example, higher loan amount and higher interest could be related with the higher borrower's expenses, which, in times of recession, would be the reason of default. For DTI, positive effect shows, that the borrower's disposable income is reduced by existing loan(s) repayments. In addition, if person has dependents (children), this residual value of income is tightened even more. Finally, the usefulness of credit rating (which is considered as one of the main tools for investors to assess the loan quality) assigned for every borrower by $\mathrm{p} 2 \mathrm{p}$ platform operator or by external institution is still debatable and must be examined due to variation in results.

Most of research in this area is based on the data from the United States' or China's p2p market. For ex., R. Emekter et al. (2015) studied credit risk and loan performance in "Lending club" p2p platform (USA). Authors revealed that the credit rating given by the platform operator predicts possibility of borrower's default (positive effect). While DTI and number of open credit positions had a statistically significant negative effect. The effect of open credit positions shows that, the more open positions borrower has, the lower his probability to default. It can be partly explained that those open positions can be loans for refinancing of previous ones. DTI effect on default probability can be interpreted as out of scope result, because the higher the DTI (which is bad signal), should be related with higher probability of default. Similar results achieved by the C. Serrano-Cinca et al. (2015). M. Malekipirbazari and V. Aksakalli (2015) examined default probability in "Lendind Club" platform. By including 23 different variables, authors found that provided credit ratings do not allow to predict borrower's defaults accurately. Therefore, these results contradict the effectiveness of credit rating as a tool of measuring probability of default. Y. Guo et al. (2016) evaluated that the ownership status has a biggest and positive impact on default probability, meaning that if debtors do not own real estate but rent it, the credit risk is higher ("Lending club" and "Prosper" data).

Another part of studies analyses borrowers default risk in China's p2p platforms. For example, X. Lin et al. (2017) examined relationship between credit risk factors and debtor's default in "Yooli" platform. 


\section{Table 1. Summary of research on determinants of credit risk in P2P platforms}

\begin{tabular}{|c|c|c|c|}
\hline Authors & Study period & Objective & Results \\
\hline $\begin{array}{l}\text { Lin, Prabhala } \\
\text { and Viswanathan } \\
(2013) \text {. }\end{array}$ & $\begin{array}{l}2007-2008 . \\
205132 \text { loans. }\end{array}$ & $\begin{array}{l}\text { Friends network effect } \\
\text { on default probability } \\
\text { in United States p2p. }\end{array}$ & Friends, who bid or won - positive relationship. \\
\hline $\begin{array}{l}\text { Barasinska and } \\
\text { Schafer (2014). }\end{array}$ & $\begin{array}{l}\text { 2007-2010 } \\
4146 \text { loans. }\end{array}$ & $\begin{array}{l}\text { Funding success } \\
\text { between genders in } \\
\text { German's p2p. }\end{array}$ & $\begin{array}{l}\text { Interest rate, financial burden - positive } \\
\text { relationship; } \\
\text { Loan amount - negative relationship. }\end{array}$ \\
\hline $\begin{array}{l}\text { Emekter et al. } \\
(2015) \text {. }\end{array}$ & $\begin{array}{l}2007-2012 \\
61451 \text { loans. }\end{array}$ & $\begin{array}{l}\text { Credit risk and loan } \\
\text { performance in United } \\
\text { states } \mathrm{p} 2 \mathrm{p} \text {. }\end{array}$ & $\begin{array}{l}\text { Credit ratings - positive relationship; } \\
\text { DTI and open credit positions - negative } \\
\text { relationship. }\end{array}$ \\
\hline $\begin{array}{l}\text { Serrano-Cinca, } \\
\text { Gutiérrez-Nieto } \\
\text { and López-Pala- } \\
\text { cios }(2015) \text {. }\end{array}$ & $\begin{array}{l}\text { 2008-2014 } \\
2449 \text { loans. }\end{array}$ & $\begin{array}{l}\text { Determinants of } \\
\text { default in United States } \\
\text { p2p. }\end{array}$ & $\begin{array}{l}\text { Credit rating - positive relationship; } \\
\text { Number of loan requests, loan amount and DTI - } \\
\text { negative relationship. }\end{array}$ \\
\hline $\begin{array}{l}\text { Malekipirbazari, } \\
\text { and Aksakalli } \\
(2015) \text {. }\end{array}$ & $\begin{array}{l}2012-2014 \\
350 \text { thousand } \\
\text { loans. }\end{array}$ & $\begin{array}{l}\text { Default probability in } \\
\text { United States p2p. }\end{array}$ & $\begin{array}{l}\text { Credit ratings do not allow predicting borrower's } \\
\text { default. }\end{array}$ \\
\hline Guo et al. (2016). & 6144 loans. & $\begin{array}{l}\text { Credit risk - return } \\
\text { assessment in United } \\
\text { States p2p. }\end{array}$ & $\begin{array}{l}\text { Ownership status, number of loan requests and } \\
\text { loan amount - positive relationship; } \\
\text { DTI and credit rating - negative relationship. }\end{array}$ \\
\hline $\begin{array}{l}\text { Lin, Li and Zheng } \\
\text { (2017). }\end{array}$ & $\begin{array}{l}2015.01 .01 \\
-2015.05 .30 \\
48784 \text { loans. }\end{array}$ & $\begin{array}{l}\text { Relationship between } \\
\text { credit risk factors and } \\
\text { debtors' default in } \\
\text { China's p2p. }\end{array}$ & $\begin{array}{l}\text { Gender, education, working experience, company } \\
\text { size - negative relationship; } \\
\text { Age, DTI, loan amount and monthly payments - } \\
\text { positive relationship. }\end{array}$ \\
\hline $\begin{array}{l}\text { Zhang et al. } \\
\text { (2017). }\end{array}$ & $\begin{array}{l}2014.01 .01 \\
-2014.06 .01 \\
193614 \text { loans. }\end{array}$ & $\begin{array}{l}\text { Determinants of de- } \\
\text { fault in China's p } 2 \mathrm{p} \text {. }\end{array}$ & $\begin{array}{l}\text { Repayment period, number of descriptions, num- } \\
\text { ber of defaults before - negative relationship; } \\
\text { Interest rate, credit rating, gender, number of suc- } \\
\text { cessfully funded loans - positive relationship. }\end{array}$ \\
\hline $\begin{array}{l}\text { Freedman and Jin } \\
\text { (2017). }\end{array}$ & $\begin{array}{l}2006-2008 \\
25008 \text { loans. }\end{array}$ & $\begin{array}{l}\text { Relationship between } \\
\text { social ties in p2p plat- } \\
\text { form and probability } \\
\text { of default. }\end{array}$ & $\begin{array}{l}\text { Connection through social network in } \mathrm{p} 2 \mathrm{p} \text { plat- } \\
\text { forms - positive relationship. }\end{array}$ \\
\hline $\begin{array}{l}\text { Riggins and } \\
\text { Weber (2017). }\end{array}$ & $\begin{array}{l}\text { 2005-2010 } \\
97226 \text { loans. }\end{array}$ & $\begin{array}{l}\text { Information asymme- } \\
\text { try and probability of } \\
\text { default in global } \mathrm{p} 2 \mathrm{p} \text {. }\end{array}$ & $\begin{array}{l}\text { Loan type, region, number of days until the loan } \\
\text { was financed, number of characters of borrower's } \\
\text { description, gender, picture and URL in p2p } \\
\text { platform - negative relationship. }\end{array}$ \\
\hline Ge et al. (2017). & $\begin{array}{l}2011-2013 \\
35457 \text { loans. }\end{array}$ & $\begin{array}{l}\text { Disclosed borrower's } \\
\text { information, provided } \\
\text { in the social media } \\
\text { effect on default. }\end{array}$ & $\begin{array}{l}\text { Disclosed information, loan amount and interest } \\
\text { rate, age, gender - negative relationship; } \\
\text { Loan term - positive relationship. }\end{array}$ \\
\hline Liu et al. (2018). & $\begin{array}{l}2012-2015 \\
8629 \text { loans. }\end{array}$ & $\begin{array}{l}\text { Borrowers probability } \\
\text { of default in China's } \\
\text { p2p. }\end{array}$ & $\begin{array}{l}\text { Loan amount, interest rate, education - positive } \\
\text { relationship; } \\
\text { Credit rating, income level - negative } \\
\text { relationship. }\end{array}$ \\
\hline $\begin{array}{l}\text { Ding et al. } \\
(2018) \text {. }\end{array}$ & $\begin{array}{l}2012-2014 \\
142290 \text { loans. }\end{array}$ & $\begin{array}{l}\text { Information asymme- } \\
\text { try problem in China's } \\
\text { peer-to-peer platform. }\end{array}$ & $\begin{array}{l}\text { Successful debtor's performance, higher education } \\
\text { and employment level - negative relationship; } \\
\text { Loan interest rate - positive relationship. }\end{array}$ \\
\hline
\end{tabular}


Among significant variables, borrower's gender had the highest negative effect on default indicating that if the borrower is female, default rate is lower than male. Y. Zhang et al. (2017) determined that repayment period, number of descriptions, number of earlier defaults had a negative, while interest rate, credit rating, number of successfully funded loans and gender had a positive effect on borrower's default.

Another group of studies analyze defaults in $\mathrm{p} 2 \mathrm{p}$ platforms from borrower's social approach. X. Lin et al. (2013) examined the friends network effect (borrowers lending platform account is related with social network account) on default probability in the United States' p2p platforms. The authors determined that only friends, who both, bid or won, had a significant positive effect on probability of default, meaning the bigger number of friends that participated in loan funding, the higher the probability of default. S. Freedman and G. Z. Jin (2017) analysed relationship between social ties in $\mathrm{p} 2 \mathrm{p}$ platform and probability of default. Authors found out that connection through social network in $\mathrm{p} 2 \mathrm{p}$ platforms increases the probability to get lower interest rate or even the probability of default. These results support the findings of X. Lin et al. (2013).

In summary, it can be said that different researchers, investigating determinants of default in $\mathrm{p} 2 \mathrm{p}$ platforms, have applied different methods involving a broad range of credit risk factors. The majority of studies found a statistically significant impact of credit risk factors on borrower's default. Therefore, it means, that investors have an opportunity to take advantage by analysing specific factors before making a decision to finance a loan. However, the research results are contradictory. These differences occur due to the different periods of analysis, methods, and countries. That is why the importance of research of borrower's default risk factors in $\mathrm{p} 2 \mathrm{p}$ platforms still exists, especially in countries like Lithuania, where $\mathrm{p} 2 \mathrm{p}$ platforms are new investing (financing) tool and the results of research can strongly differ from the previous studies and reveal new tendencies.

\section{Research methods}

Research object: Determinants of default in Lithuanian p2p market.

Data sample: This study examines credit risk determinants that can cause a borrower's default in Lithuanian $\mathrm{p} 2 \mathrm{p}$ market. According to the data of the Bank of Lithuania there were three operating peer-to-peer platforms in Lithuania that complied the research profile (active form of traditional consumer loans p2p platforms): "Finbee", "Savy" and "NEO finance". All these platforms started operating since 2015. According to the amount of loans provided, companies share the market the following way: Finbee (30\%); Savy (31\%), Neo finance (39\%). It can be stated that there is no clear leader in Lithuanian p2p market. The data set for this study was retrieved from "Finbee" platform database. It covers loans granted from August 2015 to October 2018. One of the criteria for selecting loans for research, was that loan has to be already confirmed by the platform operator. Six loans were deleted due this criterion. Another criterion was related with the availability of borrower's information in loan application, due to which two loans 
were withdrawn from the sample. Our final sample contains 6324 loans with total value of 12,8 million euros.

Description of variables: Based on the previous research a set of variables was selected. Each variable and its measurement method are explained.

Dependent variable $(Y)$ - default. It is a binary variable, that obtains value 1 , if the borrower has defaulted on a loan and value 0 if not. Previous empirical research considers the borrower's position as "default" when the payment of loan is more than 90 days late (120 in some cases). Due to the specificity of the dataset, in this research "default" means that debtor is late to pay its obligations at least 1 day. According to our definition of default, 804 loans are defaulted ( $13 \%$ of sample).

Independent variables $(\mathrm{X})$ :

Loan purpose. "Finbee" p2p platform divides loan purpose into 7 different groups: consolidation of previous loans (28\%), loans for holidays/travelling (1\%), medical expenses loans (3\%), loans suited for business purpose (2\%), car loans (11\%), home improvement loans (15\%) and other loans (40\%), which are all the remaining loans that are not covered by the previous groups. C. Serrano-Cinca et al. (2015), F. J. Riggins and D. M. Weber (2017) also included loan purpose as a possible factor that effects default.

Loan period. Loan period is measured in months and it shows how long it will take to fully repay the loan (if not earlier). In order to obtain a more accurate effect of the variable, loan period is divided by 10 . As the increase of loan period by one month can be not enough to evaluate possible effect on borrower's default, that is why 10-month changes are used. Y. Zhang et al. (2017) found a negative effect of loan period length to probability of borrower's default, while R. Ge et al. (2017) - positive.

Loan interest rate. It is an annual interest rate paid by borrowers to investors. According to C. Serrano-Cinca et al. (2015) in case of a risky investment, investors require an additional interest rate risk premium in addition to the risk-free interest rate that is already in account. The difference between these interest rates are linked to the quality of the loan and can be seen as a potential risk factor for borrower's default. Very high interest rate can result in borrower's default. N. Barasinska and D. Schafer (2014), Y. Zhang et al. (2017), Y. Liu et al. (2018), J. Ding et al. (2018) found positive relationship between interest rate and probability of default, while R. Ge et al. (2017) - negative.

Debt to income ratio (DTI). This ratio shows household's balance between debt and income: the ratio of payments of new and existing loans / disposable monthly income. According to the regulations of Responsible Lending, debt to income ratio cannot overcome $40 \%$ in Lithuania. This ratio is a tool to evaluate debtor's ability to fulfil his financial obligation. This ratio can replace loan amount variable, as it better reflects household's financial difficulties. Researchers found contradictory DTI effect on probability of default.

Borrower's education. Binary variable, which shows borrower's education level: high school (12 years in school), graduate (bachelor's degree), post graduate (master or $\mathrm{PhD}$ degree) and vocational education (professional qualification). According to "Finbee" loan portfolio distribution, borrowers with high school education covers $42 \%$, graduates - $21 \%$, post graduates $-5 \%$ and vocational education 
$32 \%$ of all outstanding loans. The majority $(74 \%)$ of borrowers have lower level of education. X. Lin et al. (2017), J. Ding et al. (2018) found negative relationship between education level and borrower's default, while Y. Liu et al. (2018) - positive relationship.

Borrower's age. Variable, which shows debtor's age, is divided by 10 following the same logic as in previously discussed variable "loan period". X. Lin et al. (2017) found positive relationship between the debtor's age and probability of default, while R. Ge et al. (2017) - negative. Positive relationship indicates, that the older the borrower, the higher the probability of default. If a person is getting older, his/her chances to find a new job decreases and probability to lose the current one - increases. Moreover, time till retirement also decreases. On the contrary, negative relationship indicates, that an older person has more knowledge and experience in the labour market, which gives him/her advantage.

Borrower's employment status: $\mathrm{Bi}$ nary variable, which shows employment status of a borrower at the time of loan request. This variable is divided into five groups: employed ( $95 \%$ of loan portfolio), self-employed ( $2 \%$ of loan portfolio), employed part time (3\% of loan portfolio), unemployed ( $0 \%$ of loan portfolio) and student ( $0 \%$ of loan portfolio).

Years of employment: This independent variable shows total amount of years that borrower has been employed. Similar to the variable "borrower's age", the years of working are divided by 5 , to check the effect on probability of default after 5 extra working years. X. Lin et al. (2017) and J. Ding et al. (2018) found a negative relationship between working experience and probability of default.
Dependents: Variable, which shows households number of dependents, younger than 18 years old. This type of variable is not commonly used in previous studies, but it can be considered as a factor of borrower's default, because higher number of dependents can be related with the higher probability of default.

Borrower's marital status: Binary variable, which is divided into 4 groups: single (39\% of portfolio), married $(41 \%$ of portfolio), divorced (17\% of portfolio) and others, which is not assigned to any of these three groups ( $3 \%$ of portfolio). Previous researchers used marital status as a credit risk factor. The statistically significant relationship between this variable and probability of default was not found in earlier studies.

Borrower's gender: It is a binary variable, that obtains value 1 , if a borrower is a male, and 0 if she is a female. Previous findings by X. Lin et al. (2017) indicated that female borrowers are less likely to default than male ones.

Credit rating provided by the platform operator. It is one of the main variables that investors are looking at. It allows evaluating possible borrower's behaviour. "Finbee" platform gives four credit ratings for debtors: "A", "B", "C" and "D". The effect of credit rating to probability of default has mixed results among researchers, same as with DTI variable.

Research method: The dependent variable "default" is binominal, as the outcome has only two option, occur or not occur. When having a "fixed" outcome the use of linear function is problematic, because the fitted probabilities can be less than zero or greater than one and the partial effect of any explanatory variable is constant (Wooldridge, 2003). Because 
of that, in linear model errors are heteroskedastic and are not normally distributed. To solve this problem, logistic regression or Logit model is used. As we can see in Table 1, almost every author used logistic regression in their researches.

By defining the measurement of the factors analysed in the study, their expression, as well as discussing the method of research, it is possible to formulate multiple logistic regression model:

$P($ default $)=1 /\left(1+e^{-}\left(\beta_{0}+\beta_{1}\right.\right.$ Credit $+\beta_{2}$ Purpose + $\beta_{3}$ Period $+\beta_{5}$ Educ $+\beta_{6}$ Interest $+\beta_{7}$ Male $+\beta_{8}$ Age $+\beta_{9}$ Work + $\beta_{10} \operatorname{Exp}+\beta_{11}$ Marital $+\beta_{12} D T I+\beta_{13}$ Child $\left.+\varepsilon_{\mathrm{i}}\right)$

Where: default - borrower's default; credit - borrower's credit rating; purpose - loan purpose; period - loan period; educ borrower's education; interest - interest rate; male - borrowers gender; age - borrowers age; work - employment status; exp - working experience; marital - borrowers marital status; DTIdebt to income ratio; child - number of dependents.

Limitations of the study. Even though the variable and research method selection are appropriate for the assessment of credit risk factors on the probability of default, however, it is necessary to review the limitations of this study. First, our sample size covers $30 \%$ of the Lithuania's $\mathrm{p} 2 \mathrm{p}$ market and the selected sample size is relatively small comparing with previous research. This problem is in line with the second one, that the time period of research is relatively short. It means that the short period does not include economic cyclicality. Moreover, during different economic periods, credit risk variables, that cause borrower's default in the short term, can significantly change in the long run. Finally, the criteria for defaulted loans selection are also discussable, as payments, that are late less than 5 days, can be considered as technical barrier, but not a borrower's default. That is why, our selection criteria can underrate customers that are actually paying on time.

\section{Research results}

Due to rapidly changing economic conditions, corporate financial environment and political events, the impact of credit risk factors on probability of default is changing as well. That is why it is necessary to update and extend the existing research. Moreover, as mentioned before,

\section{Peer-to-peer lending statistics in Lithuania}

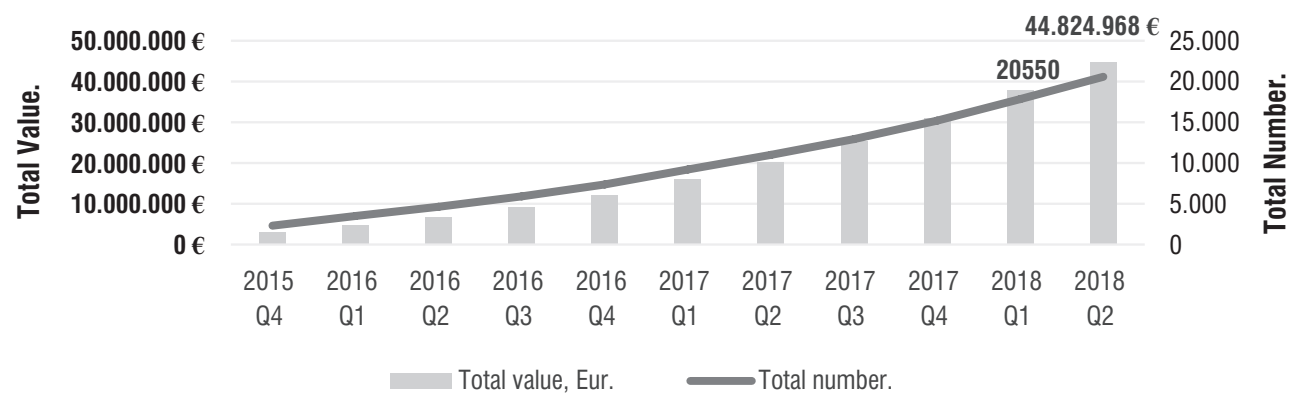

Fig. 2. Peer-to-peer lending statistics in Lithuania 2015-2018 
studies, that analysed the determinants of probability of default in Lithuanian $\mathrm{p} 2 \mathrm{p}$ market are lacking, even though the market is growing (Figure 2).

The list of crowdfunding platforms contains 12 companies currently operating in Lithuania but only 3 intermediate credit provision to individuals and do not engage in consumer credit provision by themselves. Figure 2 represents the aggregate dynamics (value in euro and number of units) of those three $\mathrm{p} 2 \mathrm{p}$ platforms. The total value and number of loans is growing rapidly over analysed period reaching almost 45 million euro of loan portfolio in the second quarter of 2018. Loans' portfolio value increased by $32 \%$ per quarter on average (121\% increase comparing 2018 IIQ with 2017 IIQ), while number of loans on average increases about $25 \%$ per quarter (87\% increase comparing 2018 IIQ with 2017 IIQ). These tendencies indicate, that there is an increasing interest in $\mathrm{p} 2 \mathrm{p}$ lending. The constantly increa- sing $\mathrm{p} 2 \mathrm{p}$ market provides more investing opportunities for individuals, but uncertainty in this market creates necessity to understand and evaluate credit risk and borrowers possible default.

Descriptive statistics analysis of the variables of credit risk. Descriptive statistics of borrowers' characteristics in the Lithuanian $\mathrm{p} 2 \mathrm{p}$ market is presented in Table 2.

As shown in Table 3, only 6.3\% from analysed 6324 loans have credit A (highest rating), while rating $\mathrm{D}$ accounts for $24.5 \%$ of loans. Loan period indicates, that average loan length is about 32-33 months, while maximum value reaches 60 (5 years is maximum possible loan period according to the law). Loan interest rate varies from $6.4 \%$ to $39.3 \%$, with the mean value is $20,2 \%$. Debt to income ratio indicates, that the lowest ratio reaches $9 \%$, while highest $40 \%$, which is ratio ceiling based on law. According to statistics, more female borrowers $(52.1 \%)$ use $\mathrm{p} 2 \mathrm{p}$ platforms

Table 2. Descriptive statistics of variables

\begin{tabular}{|c|c|c|c|c|c|}
\hline Variable & Mean & Median & Minimum & Maximum & Std. Dev. \\
\hline Credit_A & 0.063 & 0.000 & 0.000 & 1.000 & 0.244 \\
\hline Credit_B & 0.381 & 0.000 & 0.000 & 1.000 & 0.486 \\
\hline Credit_C & 0.311 & 0.000 & 0.000 & 1.000 & 0.463 \\
\hline Credit_D & 0.245 & 0.000 & 0.000 & 1.000 & 0.430 \\
\hline loan_period10 & 3.261 & 3.000 & 0.300 & 6.000 & 1.566 \\
\hline effective_rate & 0.202 & 0.202 & 0.064 & 0.393 & 0.055 \\
\hline Male & 0.479 & 0.000 & 0.000 & 1.000 & 0.500 \\
\hline Female & 0.521 & 1.000 & 0.000 & 1.000 & 0.500 \\
\hline Age10 & 3.765 & 3.600 & 1.800 & 7.000 & 1.139 \\
\hline Years_working5 & 2.687 & 2.200 & 0.060 & 9.400 & 2.023 \\
\hline dependents & 0.704 & 0.000 & 0.000 & 8.000 & 0.903 \\
\hline dti & 0.260 & 0.267 & 0.009 & 0.400 & 0.099 \\
\hline
\end{tabular}

Source: created by the authors, according to "Finbee" loan portfolio statistics. 
than male borrowers (47.9\%). Borrower's age is changing from 18 to 70 years, with the average of 37-38 years. This mean value indicates that majority of borrowers are middle-aged. According to descriptive statistics, every borrower, on average, has 13,4 years of working experience. Finally, the number of dependents ranges from zero to eight, with approximately one dependent for household on average.

Distribution of defaulted loans according to their characteristics. According to borrower's marital status, status "single" has the highest percentage of defaults (49\%), while married borrowers - $31 \%$. Moreover, male borrowers have more defaulted loans (57\%) comparing to female $(43 \%)$ ones. More than half (53\%) of defaulted loans are from borrowers with high school education and 23\% of defaulted loans from debtors with vocational education. Only $4 \%$ of defaulted loans are from borrowers with master or $\mathrm{PhD}$ degree. According to credit ratings, the credit rating " $\mathrm{A}$ " has a lowest portion of defaulted loans ( $1 \%)$, while rating " $D$ ", which is considered as the riskiest, $-43 \%$. From loan purpose perspective, we can see that the highest default percentage is among consolidation of previous loans (36\%) and other loans (34\%). There is no big difference between number of dependents, as a mean value varies from 070 to 0.74 comparing defaulted and non-defaulted loans. Mean value of age variable shows, that for defaulted loans borrower's age was approx. 35 years, while for nondefaulted borrowers - 38 years. We can state, that interest rate is related with probability of default. Average interest rate of defaulted loans is about $23 \%$, while for non-defaulted - 20\%. Finally, loan period indicates that for defaulted loans loan pe- riod is approximately 37 months on average (32 months for non-defaulted loans).

Results of Logistic regression analysis. The aim of this paper is to investigate credit risk determinants that affects probability of default in the Lithuanian p2p market. Results are summarized in Table 3.

Overall model is statistically significant, maximum likelihood chi square test's $\mathrm{p}$ value $<0,01$. Moreover, all standard errors in the model are below 2 . This indicates that we do not have significant multicollinearity between regressors in our model. Variables "unemployed" and "student" were omitted from regression because of the small sample size (only 2 loans). Moreover, variables that explain marital status, there may be existing collinearity problem, that is why variable "divorced" (which can be interpreted as single) was remodelled and variable "other" was removed from the data sample (due to the lack of transparency).

From loan characteristics, such as purpose, only loan for cars (negative) and business loans has (positive) effect on borrowers' default. These results partly support findings of C. Serrano-Cinca et al. (2015). These authors also found that business loans are the riskiest among other purposes. Regression results confirmed that credit rating, provided by the platform operator, has a negative effect on borrowers' default. Moreover, the better the rating, the more it is likely that borrower would not default. Thus, we can say, that credit rating can reflect useful information for investors. This finding relates with Y. Guo et al. (2016), Y. Liu et al. (2018) research results. Moreover, these authors used sample size which is similar with the current research. Loan period is also related with the higher 
Table 3. Logistic regression results

\begin{tabular}{|c|c|c|c|c|c|c|}
\hline Variables & Coefficient & Std. Error & $\mathbf{z}$ & p-value & VIF & $\beta(1 / \beta)$ \\
\hline const & -3.327 & 0.399 & -8.338 & $<0.0001, * * *$ & - & \\
\hline Other_purposes & -0.085 & 0.101 & -0.837 & 0.4029 & 1.704 & \\
\hline Home_Improvements & 0.028 & 0.128 & 0.221 & 0.8252 & 1.436 & \\
\hline Car & -0.343 & 0.150 & -2.288 & $0.0222, * *$ & 1.336 & 1.409 \\
\hline HolidaysTravelling & -0.356 & 0.411 & -0.865 & 0.3869 & 1.063 & \\
\hline Medicalexpenses & -0.296 & 0.272 & -1.091 & 0.276 & 1.105 & \\
\hline BusinessPurposes & 0.625 & 0.272 & 2.298 & $0.0216, * *$ & 1.135 & 1.868 \\
\hline Credit_A & -1.638 & 0.405 & -4.047 & $<0.0001, * * *$ & 2.360 & 5.145 \\
\hline Credit_B & -0.746 & 0.162 & -4.610 & $<0.0001, * * *$ & 4.160 & 2.109 \\
\hline Credit_C & -0.282 & 0.107 & -2.633 & $0.0085, * * *$ & 2.053 & 1.326 \\
\hline loan_period 10 & 0.175 & 0.031 & 5.683 & $<0.0001,{ }^{* * *}$ & 1.479 & 1.191 \\
\hline effective_rate & 5.467 & 1.231 & 4.441 & $<0.0001, * * *$ & 3.324 & 236.749 \\
\hline Male & 0.284 & 0.083 & 3.422 & $0.0006, * * *$ & 1.082 & 1.328 \\
\hline Age10 & 0.193 & 0.084 & 2.310 & $0.0209, * *$ & 5.643 & 1.213 \\
\hline Graduate & -0.448 & 0.122 & -3.672 & $0.0002, * * *$ & 1.280 & 1.565 \\
\hline Post_Graduate & -0.051 & 0.204 & -0.250 & 0.8028 & 1.126 & \\
\hline Vocational_education & -0.192 & 0.093 & -2.062 & $0.039, * * *$ & 1.247 & 1.212 \\
\hline SelfEmployed & 0.426 & 0.258 & 1.654 & $0.0982, *$ & 1.088 & \\
\hline EmployedPartTime & -0.036 & 0.263 & -0.138 & 0.8900 & 1.012 & \\
\hline Years_working5 & -0.145 & 0.049 & -2.973 & $0.0029, * * *$ & 5.474 & 1.156 \\
\hline dependents & 0.064 & 0.045 & 1.423 & 0.1548 & 1.139 & \\
\hline Married & -0.399 & 0.096 & -4.159 & $<0.0001,{ }^{* * *}$ & 1.324 & 1.490 \\
\hline dti & -0.831 & 0.421 & -1.975 & $0.0483, * *$ & 1.097 & 2.296 \\
\hline
\end{tabular}

Source: created by the authors. Dependent variable is default. *,***** represents $10 \%, 5 \%, 1 \%$ confidence levels.

probability of default. Authors Y. Guo et al. (2016) found positive relationship, while Y. Zhang et al. (2017) - negative. Different loan periods could be the factor for such results. Borrowers with education level higher than high school has negative effect on borrowers' default. This result confirms X. Lin et al. (2017) findings. This is related with the possibility for borrowers who have higher education level to have a better-paid job or to find a new one faster in case of unemployment. Another factor, which has a negative effect on probability of default, is working experience. X. Lin et al. (2017) and J. Ding et al. (2018) obtained similar results: longer working experience reduce the chances for borrower to default. Borrowers age in the current research was found to have a positive effect on his default, supporting findings of X. Lin et al. (2017). Male borrowers are more likely to default, comparing with the female ones. X. Lin et al. (2017), R. Ge et al. (2017), F. J. Riggins and D. M. Weber (2017) found similar gender effect. We can interpret that women are more rational and responsible for their 
financial obligations than men. Marital status is also significant factor, when evaluating borrower's default. We found that married borrowers are less likely to default than single ones. It can be interpreted that married borrowers have more possibilities to obtain necessary funds for financial obligations, because it is more likely that both family members are working. In this study, one of the regression models indicated significant and negative effect of debt to income ratio. Therefore, obtained results support findings of R. Emekter et al. (2015), C. Serrano-Cinca et al. (2015), Y. Guo et al. (2016). This negative relationship can be interpreted as a sign of shadow economy. It is possible that borrowers obtain income from other sources, which are not included in the calculation of DTI. So even if borrower has a high DTI ratio, investors cannot take this factor as a sign of default. Finally, the interest rate has positive effect on probability of default. Meaning that if interest rate would increase, probability that borrower defaults increases. This factor has the strongest effect on possible borrowers' default among other credit risk factors. The authors N. Barasinska and D. Schafer (2014), Y. Zhang et al. (2017), X. Liu et al. (2018), J. Ding et al. (2018) found similar results.

Summarizing the results of logistic regression, we can say that these significant credit risk factors may show information for investors and other interested parties about possible borrowers' default. Even though, some of the obtained results support and some of them contradict previous research, but the necessity of this study is obvious. Investors must carefully evaluate every credit risk factor in order to avoid borrowers' default.

\section{Conclusions}

After summarizing previous empirical research on credit risk factors that affect probability of default, we can state, that there is a significant relationship between these phenomena. However, the results according to different credit risk factors are contradictory. These differences occur due to the different research periods, applied methods or country of analysis.

According to statistics, the Lithuanian p2p market is constantly growing. The increase of importance of this financial innovation creates uncertainty for investors, how to manage their investments safely in order to avoid borrowers' default. According to the results of logistic regression analysis, ten credit risk variables out of twelve were statistically significant. Loan purpose for a car had negative, while business loans positive effect comparing with loans for debt consolidation. Loan period and interest rate had a positive effect on probability of default. Borrower's characteristics, such as education (higher than high school) and working experience had a negative effect on borrower's default. However, age is related with higher probability of default. Results also show that females and married borrowers are less likely to default. Finally, credit ratings and debt to income ratio showed a negative effect on the borrower's default.

Comparison of the results of this study with the previous research revealed that these results support and complement the majority of previous empirical findings. Finally, we can conclude that proper assessment of credit risk factors can help investors to avoid loans, which may possibly default in the future. 


\section{References}

1. Barasinska, N., Schäfer, D. (2014). Is Crowdfunding Different? Evidence on the Relation Between Gender and Funding Success from a German Peer-To-Peer Lending Platform // German Economic Review. Vol. 15, No. 4, pp. 436-452. https://doi.org/10.1111/geer.12052

2. Cai, S., Lin, X., Xu, D., Fu, X. (2016). Judging Online Peer-to-Peer Lending Behavior: A Comparison of First-Time and Repeated Borrowing Requests // Information \& Management. Vol. 53, No. 7, pp. 857-867. https://doi.org/10.1016/j.im.2016.07.006

3. Davis, K., Murphy, J. (2016). Peer to Peer Lending: Structures, Risks and Regulation. Internet access: http://kevindavis.com.au/ secondpages/acadpubs/2016/JASSA $\% 20$ Paper\%20-\%20P2P\%20Lending\%20-\%20 Davis\%20and\%20Murphy\%20-\%20final.pdf

4. Ding, J., Huang, J., Li, Y., Meng, M. (2018). Is There an Effective Reputation Mechanism in Peer-to-Peer Lending? Evidence from China // Finance Research Letters. https://doi. org/10.1016/j.frl.2018.09.015

5. Emekter, R., Tu, Y., Jirasakuldech, B., Lu, M. (2015). Evaluating Credit Risk and Loan Performance in Online Peer-to-Peer (P2P) Lending // Applied Economics. Vol. 47, No. 1, pp. 54-70. https://doi.org/10.1080/00036846.2 014.962222

6. Fong, A. (2015). Regulation of Peer-to-Peer Lending in Hong Kong: State of Play // Law and Financial Markets Review. Vol. 9, No. 4, pp. 251-259. https://doi.org/10.1080/1752144 0.2015 .1114248

7. Freedman, S., Jin, G. Z. (2017). The Information Value of Online Social Networks: Lessons from Peer-to-Peer Lending // International Journal of Industrial Organization. Vol. 51, pp. 185-222. https://doi.org/10.1016/j.ijindorg.2016.09.002

8. Funding Circle Statistics. Internet access: www. fundingcircle.com/uk/statistics/

9. Ge, R., Feng, J., Gu, B., Zhang, P. (2017). Predicting and deterring default with social media information in peer-to-peer lending // Journal of Management Information Systems. Vol. 34, No. 2, pp. 401-424. https://doi.org/10. 1080/07421222.2017.1334472

10. Guo, Y., Zhou, W., Luo, C., Liu, C., Xiong, H. (2016). Instance-Based Credit Risk Assessment for Investment Decisions in P2P Lending //
European Journal of Operational Research. Vol. 249, No. 2, pp. 417-426. doi.org/10.1016/j. ejor.2015.05.050

11. Lei, X. (2016). Discussion of the Risks and Risk Control of P2P in China // Modern Economy. Vol. 7, No. 04, pp. 399. doi: 10.4236/ me.2016.74043

12. Lichtenwald, R. (2014). The History of Peer to Peer Lending. Peer and Social Lending. Internet access: http://peersociallending.com/news/ history-peer-peer-lending/

13. Lin, M., Prabhala, N. R., Viswanathan, S. (2013). Judging Borrowers by the Company they Keep: Friendship Networks and Information Asymmetry in Online Peer-to-Peer Lending // Management Science. Vol. 59, No. 1, pp. 17-35. https://doi.org/10.1080/00036846.2016.1262526

14. Lin, X., Li, X., Zheng, Z. (2017). Evaluating Borrower's Default Risk in Peer-to-Peer Lending: Evidence from a Lending Platform in China // Applied Economics. Vol. 49, No. 35, pp. 3538-3545. https://doi.org/10.1080/000368 46.2016.1262526

15. Liu, Y., Zhou, Q., Zhao, X., Wang, Y. (2018). Can Listing Information Indicate Borrower Credit Risk in Online Peer-to-Peer Lending? // Emerging Markets Finance and Trade. Vol. 54, No. 13, pp. 2982-2994. https://doi.org/10.1080/ 1540496X.2018.1427061

16. Ma, H. Z., Wang, X. R. (2016). Influencing Factor Analysis of Credit Risk in P2P Lending Based on Interpretative Structural Modeling // Journal of Discrete Mathematical Sciences and Cryptography. Vol. 19, No. 3, pp. 777-786. https://doi.org/10.1080/09720529.2016.1178935

17. Malekipirbazari, M., Aksakalli, V. (2015). Risk Assessment in Social Lending Via Random Forests // Expert Systems with Applications. Vol. 42, No. 10, pp. 4621-4631. https://doi. org/10.1016/j.eswa.2015.02.001

18. Mateescu, A. (2015). Peer-to-Peer Lending. Data \& Society Research Institute, pp. 19-25. Internet access: https://www.datasociety.net/ pubs/dcr/PeertoPeerLending.pdf

19. Milne, A., Parboteeah, P. (2016). The Business Models and Economics of Peer-to-Peer Lending. Internet access: http://dx.doi.org/10.2139/ ssrn.2763682

20. Pokorna, M., Sponer, M. (2016). Social Lending and its Risks // Procedia-Social and Behavioral 
Sciences. Vol. 220, pp. 330-337. https://doi. org/10.1016/j.sbspro.2016.05.506

21. Republic of Lithuania Law on Consumer Credit. No. XII-1989. Internet access: https://e-seimas. lrs.lt/portal/legalAct/lt/TAD/5c534e403c5c11e6 8f278e2f1841c088?jfwid=-vkzfyh270

22. Riggins, F. J., Weber, D. M. (2017). Information Asymmetries and Identification Bias in P2P Social Microlending // Information Technology for Development. Vol. 23, No. 1, pp. 107-126. https://doi.org/10.1080/0268110 2.2016.1247345

23. Serrano-Cinca, C., Gutierrez-Nieto, B., LópezPalacios, L. (2015). Determinants of Default in P2P Lending // PloS One. Vol. 10, No. 10, pp. e0139427. https://doi.org/10.1371/journal. pone. 0139427
24. Wei, S. (2015). Internet Lending in China: Status Quo, Potential Risks and Regulatory Options // Computer Law \& Security Review. Vol. 31, No. 6, pp. 793-809. https://doi.org/10.1016/j. clsr.2015.08.005

25. Wooldridge, J. M. (2003). Introductory Econometrics: A Modern Approach. - Australia; Cincinnati, Ohio: South-Western College Pub., c2003.

26. Zhang, Y., Li, H., Hai, M., Li, J., Li, A. (2017). Determinants of Loan Funded Successful in Online P2P Lending // Procedia Computer Science. Vol. 122, pp. 896-901. https://doi. org/10.1016/j.procs.2017.11.452

The paper submitted: October 23, 2018 Prepared for publication: December 20, 2018

\section{Asta GAIGALIENĖ, Dovydas ČESNYS \\ SKOLININKỤ NEMOKUMO VEIKSNIŲ VERTINIMAS LIETUVOS SAVITARPIO SKOLINIMOSI RINKOJE}

\section{$\mathrm{S}$ a n t r a u k a}

Kreditavimo rinka yra viena iš sričių, kuri susiduria su naujais pokyčiais. İ šią rinką, kaip ir ị visą finansų sektorių, žengia naujos technologijos. Šiuolaikinis klientas yra pripratęs prie skaitmeninių erdvių (pvz., „Google“, „Amazon“, „Facebook“, „eBay“), todèl jis tikisi savo turimą patirtị patenkinti ir finansinių paslaugų rinkoje. Viena iš šių alternatyvų yra tarpusavio (P2P) skolinimo platformos, kurios leidžia mums skolinti ir skolintis pinigus tarp aktyvių platformos narių be finansų tarpininkų ịsikišimo. Investuotojai susiduria su visa susijusia rizika, būdinga tradicinems paskoloms. Viena iš pagrindinių yra kredito rizika, atsirandanti dèl skolininko ịsipareigojimų nevykdymo. Todèl netinkamas kredito rizikos vertinimas gali lemti nuostolius investuotojui ir, atvirkščiai, tinkamas vertinimas gali lemti didesnę grąžąa.

Skolinimo platformos paplito vos prieš keletą dešimtmečių (Lichtenwald, 2014), o kredito rizikos veiksnių vertinimas skolinimosi platformose tapo mokslinių tyrimų objektu. İvairūs autoriai (Serrano-Cinca, Gutiérrez-Nieto ir López-Palacios, 2015; Emekter et al., 2015; Guo et al., 2016; Pokorná ir Sponer, 2016; Ma ir Wang, 2016; Lin ir Li Zheng,
2017) analizavo skirtingus kredito rizikos aspektus savitarpio skolinimo platformose. Tačiau tyrimų rezultatai yra prieštaringi ir nevienareikšmiški, t. y. kokie veiksniai ar skolininko charakteristikos galètų signalizuoti apie galimą įsipareigojimų nevykdymą tarpusavio platformose. Be to, svarbu paminèti, kad didžioji dalis mokslinių tyrimų yra sutelkta šalyse, kuriose savitarpio skolinimo rinka labiau išvystyta: JAV, Kinijoje, Jungtinèje Karalystèje, Vokietijoje ir kt. Tačiau tokių tyrimų trūksta šalyse, kuriose šios rinkos mažiau išvystytos. Lietuva galètų būti vienas iš pavyzdžių, kur turime mažiausius namų ūkių taupymo rodiklius Europoje ir kur tik atsiranda investicijų kultūra. Štai kodèl būtina atnaujinti esamus tyrimus ir įvertinti kredito rizikos veiksnių įtaką ịsipareigojimų neivvykdymo tikimybei naudojant šias naujas alternatyvias finansavimo priemones.

Šiame tyrime nagrinejami kredito rizikos veiksniai, galintys sukelti skolininkų įsipareigojimų nevykdymą Lietuvos P2P rinkoje. Šio tyrimo duomenys buvo gauti iš „Finbee“ platformos duomenų bazès. Tyrimas apima paskolas, suteiktas nuo 2015 m. rugpjūčio mèn. iki 2018 m. spalio mèn. Priklausomasis kintamasis šiame tyrime yra skolininko 
issipareigojimų nevykdymas. Priklausomasis kintamasis yra binarinis, o tai reiškia, kad rezultatas turi tik du variantus: yra arba ne. Tyrimo modelis apima kitus kintamuosius, tokius kaip: skolininko kredito reitingas; paskolos tikslas; paskolos laikotarpis; skolininko išsilavinimas; palūkanų norma; skolininko lytis; skolininko amžius; užimtumo statusas; darbo patirtis; skolininko šeiminė padètis; skolos įmokų ir pajamų santykis; išlaikytinių skaičius.

Remiantis statistiniais duomenimis, Lietuvos savitarpio skolinimo rinka nuolat auga. Didejant šio finansinio produkto svarbai, investuotojams kyla neaiškumų, kaip saugiai valdyti savo investicijas, kad būtų išvengta skolininkų îsipareigojimų nevykdymo. Remiantis logistinès regresijos analize, dešimt kredito rizikos kintamųjų iš dvylikos buvo statistiškai reikšmingi. Pvz., paskolos laikotarpis ir palūkanų norma teigiamai veikia įsipareigojimų neịvykdymo tikimybę. Skolininkų charakteristikos, pavyzdžiui, išsilavinimas (aukštesnis nei vidurinis) ir ilgesnè darbo patirtis, neigiamai veikia skolininkų i̇sipareigojimų nevykdymo tikimybę. Tačiau amžius yra susijęs su didesne ịsipareigojimų nevykdymo tikimybe. Rezultatai taip pat rodo, kad moterys ir susituokę skolininkai yra mažiau linkę nevykdyti ịsipareigojimų. Galiausiai kredito reitingai ir skolos mokejjimų bei pajamų santykis rodo neigiamą poveikị skolininkų isipareigojimų nevykdymui. Šio tyrimo rezultatų palyginimas su ankstesniais tyrimais parodè, kad gauti duomenys patvirtina ir papildo daugumą ankstesnių empirinių tyrimų rezultatų. Taigi galima daryti išvadą, kad tinkamas kredito rizikos veiksnių vertinimas gali padèti investuotojams išvengti paskolų, kurios ateityje galbūt nebus grąžintos. 